\title{
Trichosanthin reduces the viability of SU-DHL-2 cells via the activation of the extrinsic and intrinsic apoptotic pathways
}

\author{
YINGJIE ZHU ${ }^{1,2,5^{*}}$, YUELI SUN ${ }^{3 *}$, YUCHEN CAI $^{1}$, OU SHA $^{4}$ and WENQI JIANG ${ }^{1,2}$ \\ ${ }^{1}$ State Key Laboratory of Oncology in Southern China, Collaborative Innovation Center for Cancer Medicine; \\ ${ }^{2}$ Department of Medical Oncology, Sun Yat-sen University Cancer Center, Guangzhou, Guangdong 510060; \\ ${ }^{3}$ Department of Thoracic Oncology, Guangdong Lung Cancer Institute, Guangdong General Hospital and \\ Guangdong Academy of Medical Sciences, Guangzhou, Guangdong 510080; ${ }^{4}$ Department of Basic Medical Sciences, \\ School of Medicine, Shenzhen University, Shenzhen, Guangdong 518060, P.R. China
}

Received February 11, 2015; Accepted October 6, 2015

DOI: $10.3892 / \mathrm{mmr} .2015 .4531$

\begin{abstract}
Previous studies have indicated that trichosanthin (TCS) exerts antitumor activity by inducing apoptosis in numerous tumor cell lines. However, the effects of TCS on lymphoma remain to be elucidated. The current study demonstrated that TCS inhibited the proliferation of thirteen lymphoma cell lines in a dose-dependent manner, with SU-DHL-2 cells exhibiting the greatest sensitivity to TCS. Treatment of SU-DHL-2 cells with TCS led to cell cycle arrest at the $\mathrm{S}$ to $\mathrm{G}_{2} / \mathrm{M}$ phase transition. Furthermore, flow cytometric analysis, Hoechst 33258 staining and western blotting indicated that TCS induced the apoptosis of SU-DHL-2 cells in a time- and concentration-dependent manner. In addition, the activation of caspase-3 and -7 and poly (ADP-ribose) polymerase were observed. Pharmacological pan-caspase inhibition was observed to reduce TCS-induced apoptosis. Inhibition of caspase- 8 or -9 alone was observed to partially reverse the effect of TCS on apoptosis. In conclusion, the current study indicates that TCS may induce apoptosis in SU-DHL-2 cells via the extrinsic and intrinsic pathways.
\end{abstract}

Correspondence to: Professor Wenqi Jiang, State Key Laboratory of Oncology in Southern China, Collaborative Innovation Center for Cancer Medicine, Sun Yat-Sen University Cancer Center, 651 Dong Feng Road East, Guangzhou, Guangdong 510060, P.R. China

E-mail: jiangwq@sysucc.org.cn

Professor Ou Sha, Department of Basic Medical Sciences, School of Medicine, Shenzhen University, 3688 Nan Hai Avenue, Shenzhen, Guangdong 518060, P.R. China

E-mail: shaou@szu.edu.cn

Present address: ${ }^{5}$ Institute of Tumor Pharmacology, Jinan University College of Pharmacy, Guangzhou, Guangdong 510632, P.R. China

*Contributed equally

Key words: trichosanthin, apoptosis, caspase, lymphoma, SU-DHL-2 cells

\section{Introduction}

Trichosanthin (TCS), a type I ribosome-inactivating protein (RIP), is a $27 \mathrm{kDa}$ protein isolated from the root tubers of the Chinese medicinal herb Tian-Hua-Fen (Trichosanthes kirilowii) of the Cucurbitaceae family (1). TCS is a traditional Chinese medicine which has been used as an abortifacient and for the treatment of hydatidiform moles, malignant hydatidiform moles and ectopic pregnancies due to its high toxicity to trophoblasts (2,3). Previous studies suggest that TCS has a broad spectrum of biological and pharmacological activities including immune regulatory, antivirus and antitumor activity $(1,4,5)$. Due to the selective cytotoxicity of TCS to tumor cells, TCS has gained increased research attention. It was suggested that TCS-treated cells underwent cell death due to the inhibition of cellular protein synthesis and the induction of necrosis (3). However, studies have suggested that TCS exerts antitumor activities by inducing apoptosis in numerous cell lines, including human choriocarcinoma, breast cancer, cervical cancer, nasopharyngeal carcinoma, leukemia and lymphoma cells (5-10). Therefore, TCS has been considered as a potential novel agent for antitumor treatment.

Apoptosis is an important mode of programmed cell death that occurs normally during development or as a stress response, and is an essential mechanism to selectively eliminate cells in antitumor chemotherapy and radiotherapy $(11,12)$. Central to the cell suicide program is a cascade of caspases with caspase-3 being a key terminal executor that in turn is cleaved and activated by various initiator caspases (13). There are two major pathways of apoptosis in mammalian cells: The death receptor-initiated extrinsic pathway and the mitochondria-mediated intrinsic pathway (13-15). Cross-talk exists between the extrinsic and intrinsic apoptotic pathways (16). Caspase- 8 is the initiator of the extrinsic pathway and caspase- 9 is a key executor of the instrinsic pathway. The cleavage of either caspase- 8 or -9 triggers downstream effectors, caspase-3, -6 and -7, and poly(ADP-ribose) polymerase-1 (PARP-1), which leads to a series of apoptotic events and eventually cell death $(14,15,17)$.

A previous study demonstrated that TCS is able to inhibit the proliferation of Raji and Jurkat cells (10). However, limited 
types of lymphoma cell lines have been investigated, and the mechanisms involved in the TCS-induced apoptosis in these cells remain to be elucidated. Therefore, the current study screened the potential antitumor activity of TCS in different types of lymphoma cells and identified which exhibited the greatest sensitivity to TCS. In these cells, the effects of TCS on the cell cycle, the induction of apoptosis and the underlying mechanisms were investigated. The present study provides an experimental basis for further research, and indicates that TCS may be a novel antitumor agent for the treatment of lymphoma.

\section{Materials and methods}

Chemicals. TCS was purchased from Shanghai Jinshan Pharmaceutical Co., Ltd. (Shanghai, China). Dimethyl sulfoxide was obtained from Sigma-Aldrich (St. Louis, MO, USA) and the Cell Counting Kit-8 was from Dojindo Molecular Technologies, Inc. (Kumamoto, Japan). Annexin V-fluorescein isothiocyanate (FITC) and propidium iodide (PI) were obtained from Roche Diagnostics $\mathrm{GmbH}$ (Mannheim, Germany). Hoechst 33258 was obtained from Beyotime Institute of Biotechnology (Haimen, China). The caspase-3, caspase-7, PARP-1 and glyceraldehyde 3-phosphate dehydrogenase (GAPDH) primary antibodies were supplied by Cell Signaling Technology, Inc. (Danvers, MA, USA). Carbobenzoxy-val-ala-asp-(OMe)-fluoromethylketone (Z-VAD-FMK), Z-ile-glu(OMe)-thr-asp(OMe)-FMK (Z-IETD-FMK) and Z-leu-glu(OMe)-his-asp(OMe)-FMK (Z-LEHD-FMK) were obtained from R\&D Systems, Inc. (Minneapolis, MN, USA). TCS was examined using SDS-PAGE and Coomassie Brilliant Blue staining (Bio-Rad Laboratories, Inc., Hercules, CA, USA).

Cell culture. Raji, Ramos, Namalwa (Burkitt's lymphoma), RL (follicular lymphoma), Jurkat (T-cell acute lymphoblastic leukemia) (American Type Culture Collection, Manassas, VA, USA), OCI-1y1, OCI-ly8, OCI-1y19, SU-DHL-6 (gifts from Professor Xiongzeng Zhu, Fudan University Shanghai Cancer Center, Shanghai, China), OCI-ly10, SU-DHL-2 (gifts from Professor Ru Feng, Nanfang Hospital, Southern Medical University, Guangzhou, China), SU-DHL-4 and NU-DHL-1 [diffuse large B-cell lymphoma (DLBCL)] (gifts from Professor Yanhui Liu, Guangdong General Hospital, Guangzhou, China) cell lines were used in the present study. All cell lines were grown in RPMI-1640 medium (Gibco; Thermo Fisher Scientific, Inc., Waltham, MA, USA) supplemented with $10 \%$ fetal bovine serum (Gibco; Thermo Fisher Scientific, Inc.), $100 \mathrm{U} / \mathrm{ml}$ penicillin and $100 \mu \mathrm{g} / \mathrm{ml}$ streptomycin (GE Healthcare Life Sciences, Logan, UT, USA) in a $5 \% \mathrm{CO}_{2}$ incubator at $37^{\circ} \mathrm{C}$.

Cell viability assay. A Cell Counting Kit-8 (CCK-8) assay was used to measure the sensitivity of the different cell lines to TCS. Cells were seeded at a density of $6 \times 10^{3}$ cells/well in 96-well plates. TCS was added at different concentrations (0.01953125-10.0 $\mu \mathrm{M} ; 20 \mu \mathrm{l} /$ well) into the designated wells. Following $69 \mathrm{~h}$ of incubation, $8 \mu \mathrm{l}$ of CCK-8 solution was added to each well, and the plate incubated for a further $3 \mathrm{~h}$. The absorbance values were measured at $450 \mathrm{~nm}$ using a SpectraMax M5 plate reader (Molecular Devices LLC,
Sunnyvale, CA, USA). The 50\% inhibitory concentration $\left(\mathrm{IC}_{50}\right)$ values were calculated to construct the survival curves using the Bliss method (18).

Cell cycle analysis. SU-DHL-2 cells were treated with TCS $(0.15,0.75$ and $1.50 \mu \mathrm{M})$ for $48 \mathrm{~h}$. The cells were then centrifuged at $377 \mathrm{x}$ g for $5 \mathrm{~min}$ and washed with $0.01 \mathrm{M}$ phosphate-buffered saline (PBS, $\mathrm{pH}$ 7.4) three times. Subsequently, the cells were fixed with ice-cold ethanol for a minimum of $18 \mathrm{~h}$. The cells were then washed with PBS twice and stained with PI solution, which contained $50 \mu \mathrm{g} / \mathrm{ml}$ PI, $100 \mu \mathrm{g} / \mathrm{ml}$ RNase A (KeyGen Biotech Co. Ltd., Nanjing, China) and $0.2 \%$ Triton X-100 (KeyGen Biotech Co. Ltd.). The samples were measured using a Gallios flow cytometer (Beckman Coulter Inc., Brea, CA, USA) and the data were analyzed using multiflow software (version 2.2; Beckmann Coulter, Inc.).

Annexin V-FITC/PI staining assay. An Annexin V-FITC/PI Apoptosis kit was used according to the manufacturer's instructions to quantify the percentage of cells undergoing apoptosis. SU-DHL-2 cells were incubated for $48 \mathrm{~h}$ with TCS $(0.03$, 0.15 or $0.75 \mu \mathrm{M}$ ) or with $0.75 \mu \mathrm{M}$ for $3,6,12,24$ and $48 \mathrm{~h}$. The Bcl-2/Bcl-xL inhibitor, ABT-263 (8 $\mu \mathrm{M}$; Selleckchem, Houston, TX, USA), was used as the positive control. The cells were washed twice with cold PBS and resuspended in the binding buffer (Roche Diagnostics $\mathrm{GmbH}$ ) at a concentration of $1 \times 10^{6}$ cells $/ \mathrm{ml}$. Subsequently, $5 \mu 1$ Annexin V-FITC and $10 \mu \mathrm{l}$ PI were added, and the cells were incubated for $5 \mathrm{~min}$ at room temperature in the dark. Following this, $400 \mu \mathrm{l}$ binding buffer was added and the cells were analyzed by flow cytometry. The Annexin V-FITC ${ }^{+} / \mathrm{PI}^{-}$cells were identified as apoptotic cells, and the Annexin $\mathrm{V}-\mathrm{FITC}^{+} / \mathrm{PI}^{+}$cells were identified as necrotic cells. The measurements were repeated three times for each sample.

Hoechst 33258 staining. The morphological alterations in the TCS-treated cells were investigated using Hoechst 33258 staining. Following exposure to TCS $(0.03,0.15$ or $0.75 \mu \mathrm{M})$ for $48 \mathrm{~h}$, or $0.75 \mu \mathrm{M}$ for 12,24 or $48 \mathrm{~h}$, the SU-DHL-2 cells were incubated with $20 \mu \mathrm{M}$ Hoechst 33258 for $10 \mathrm{~min}$ at room temperature. The cells were then washed twice with PBS and examined using a confocal laser scanning microscope (Olympus Fluoview FV1000; Olympus Corporation, Tokyo, Japan). Apoptotic cells were identified by Hoechst 33258 staining as exhibiting condensed chromatin and fragmented nuclei. A minimum of 10 random fields were counted for each sample.

Western blot analysis. Cells were harvested and rinsed three times with ice-cold PBS, and total cell lysates were prepared. Cell extracts were prepared by incubating cells for $30 \mathrm{~min}$ on ice with $1 \mathrm{X}$ lysis buffer [PBS with $0.1 \%$ sodium dodecyl sulfate (SDS), $1 \%$ Nonidet P-40, 0.5\% sodium deoxycholate and $100 \mathrm{mg} / \mathrm{ml} \mathrm{p}$-amino phenylmethylsulfonyl fluoride] with agitation followed by centrifugation $\left(14,000 \mathrm{x}\right.$ g at $4{ }^{\circ} \mathrm{C}$ for $20 \mathrm{~min}$ ). The supernatant containing the total cell lysates was stored at $-80^{\circ} \mathrm{C}$ prior to experiments. Cell lysates containing $30 \mu \mathrm{g}$ total protein were resolved by SDS polyacrylamide gel electrophoresis (SDS-PAGE; Bio-Rad Laboratories, Inc.) and transferred onto polyvinylidene fluoride membranes 
(Roche Diagnostics $\mathrm{GmbH}$ ). Membranes were incubated in blocking buffer [10 mmol/1 Tris- $\mathrm{HCl}(\mathrm{pH} 8.0), 150 \mathrm{mmol} / 1$ $\mathrm{NaCl}, 0.1 \%$ Tween 20 and 5\% skimmed milk] for $2 \mathrm{~h}$ at room temperature, prior to incubation with primary antibodies overnight at $4^{\circ} \mathrm{C}$. The following antibodies were used: Rabbit polyclonal anti-caspase-7 (cat. no. 9492; 1:1,000 dilution), rabbit monoclonal anti-caspase-3 (cat. no. 9665; 1:1,000 dilution), rabbit monoclonal anti-PARP-1 (cat. no. 9532; 1:1,000 dilution) and rabbit monoclonal anti-glyceraldehyde 3-phosphate dehydrogenase (GAPDH; cat. no. 2118; 1:5,000 dilution) (all from Cell Signaling Technology, Inc., Danvers, MA, USA). Subsequently, the membranes were incubated with horseradish peroxidase-conjugated goat anti-rabbit secondary antibody (1:2,000 dilution; Cell Signaling Technology, Inc.) for $1 \mathrm{~h}$ at room temperature. The protein-antibody complexes were detected using enhanced chemiluminescence reagents (Cell Signaling Technology, Inc.) and exposed to X-ray film (Eastman-Kodak Co., Rochester, NY, USA).

Statistical analysis. All experiments were repeated a minimum of three times. The data are presented as the mean \pm standard deviation. Statistical analysis was conducted using SPSS software, version 16.0 (SPSS, Inc., Chicago, IL, USA) and one-way analysis of variance. $\mathrm{P}<0.05$ was considered to indicate a statistically significant difference.

\section{Results}

TCS reduces the cell viability of lymphoma cells. The purity of TCS was examined using SDS-PAGE and Coomassie Brilliant Blue staining. A single band with a molecular mass of $27 \mathrm{kDa}$ was observed by SDS-PAGE (Fig. 1), which was in accordance with a previous study (19). To investigate the potential antitumor activity of TCS on different types of lymphoma cells, the following thirteen lymphoma cell lines were selected: Raji, Ramos, Namalwa (Burkitt's lymphoma), OCI-ly1, OCI-ly8, OCI-1y10, OCI-1y19, SU-DHL-2, SU-DHL-4, SU-DHL-6, NU-DHL-1 [diffuse large B cell lymphoma (DLBCL)], RL (follicular lymphoma) and Jurkat (T-cell acute lymphoblastic leukemia) cells. The cells were treated with different concentrations of TCS (ranging from 0.02-10 $\mu \mathrm{M}$ ) for $72 \mathrm{~h}$. Cell viability was measured using a CCK-8 assay. As presented in Fig. 2A, TCS induced a dose-dependent reduction in the viability of all thirteen tested cell lines with diverse sensitivities. Following exposure to TCS for 72 h, Jurkat, Namalwa and SU-DHL-6 cells exhibited a lower sensitivity to TCS compared with that of the other cell lines, with $\mathrm{IC}_{50} \mathrm{~s}$ of $2.20,2.47$ and $1.87 \mu \mathrm{M}$, respectively. SU-DHL-2 cells exhibited the greatest sensitivity to TCS compared with the remaining twelve cell lines. Based on the $\mathrm{IC}_{50}$ values, SU-DHL-2 cells were selected for further investigation. In addition, the reduction in viability mediated by TCS on SU-DHL-2 cells was time-dependent (Fig. 2B). Following 24, 48 and $72 \mathrm{~h}$ treatment with TCS, the $\mathrm{IC}_{50} \mathrm{~s}$ for SU-DHL-2 cells were $1.74,0.16$ and $0.07 \mu \mathrm{M}$, respectively.

TCS induces cell cycle arrest in SU-DHL-2 cells. To investigate the molecular mechanisms of the reduction in viability mediated by TCS, the cell cycle was assessed using flow cytometry. Cultured SU-DHL-2 cells were treated with $0,0.15$, 0.75 or $1.50 \mu \mathrm{M}$ TCS for $24 \mathrm{~h}$ and the percentage of cells in the

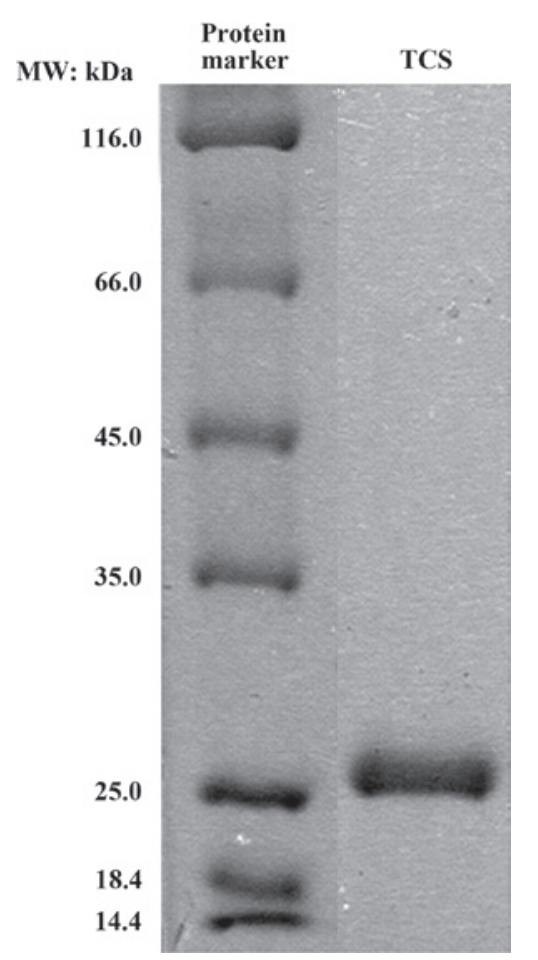

Figure 1. TCS demonstrated a single band in the sodium dodecyl sulfate-polacrylamide gel electrophoresis with a molecular weight of $27 \mathrm{kDa}$. TCS, trichosanthin.
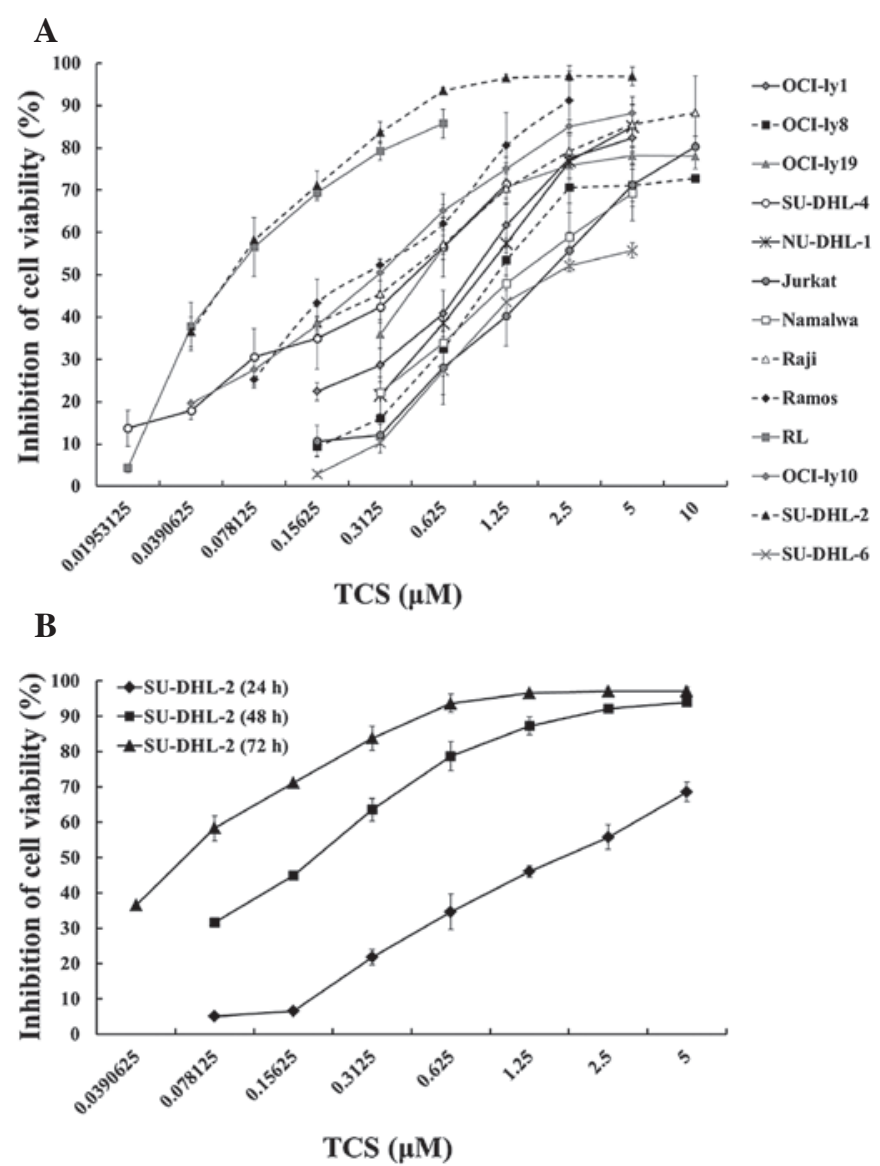

Figure 2. Effect of TCS on the viability of different lymphoma cells. (A) Cells were treated with TCS at different concentrations for $72 \mathrm{~h}$. TCS reduced the cell viability of thirteen cell lines in a dose-dependent manner. (B) The increasing concentrations of TCS resulted in a dose-dependent reduction in the viability of SU-DHL-2 cells. Values are presented as the mean \pm standard deviation from a minimum of three independent experiments. TCS, trichosanthin. 

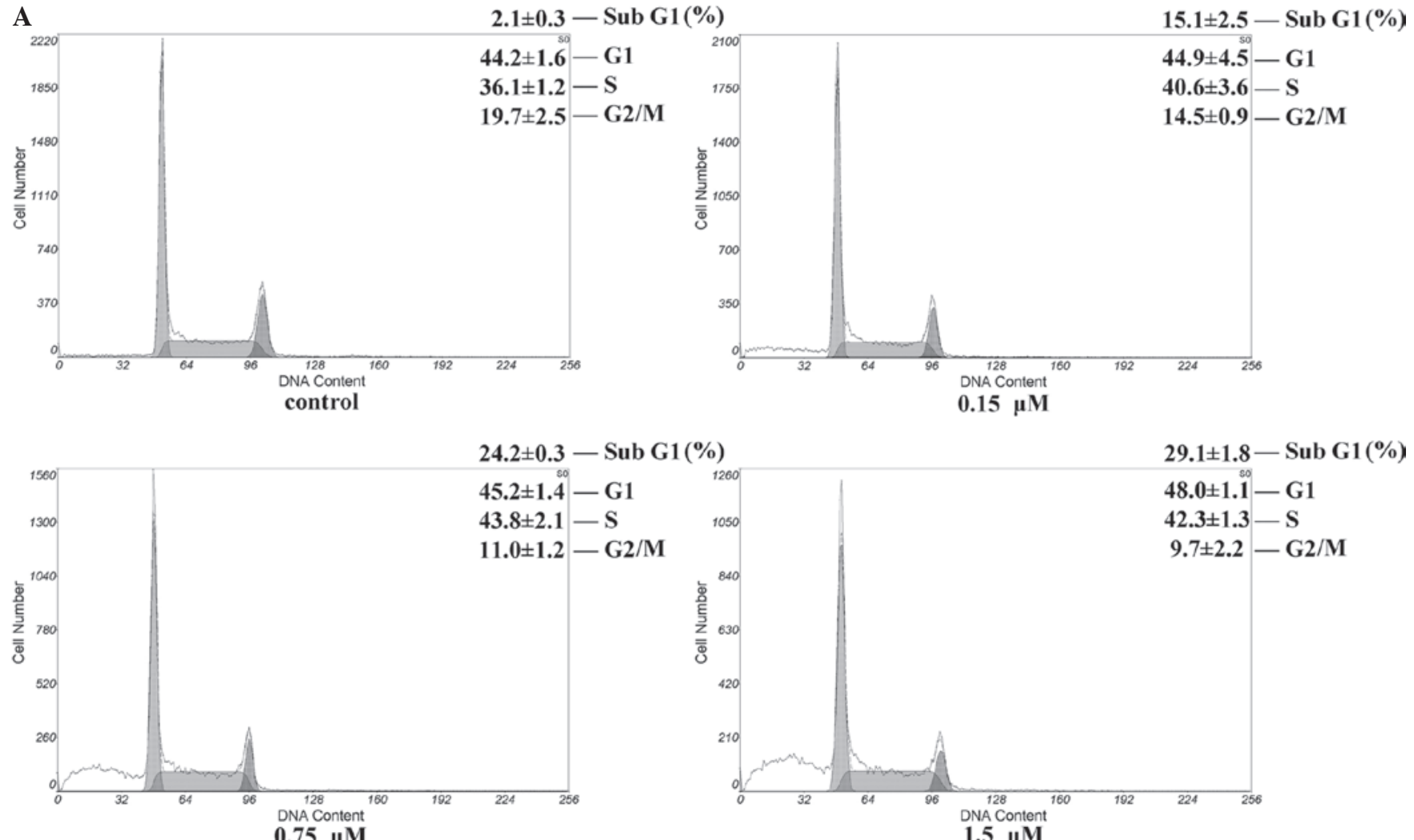

B

$0.75 \mu \mathrm{M}$

DNA Conten

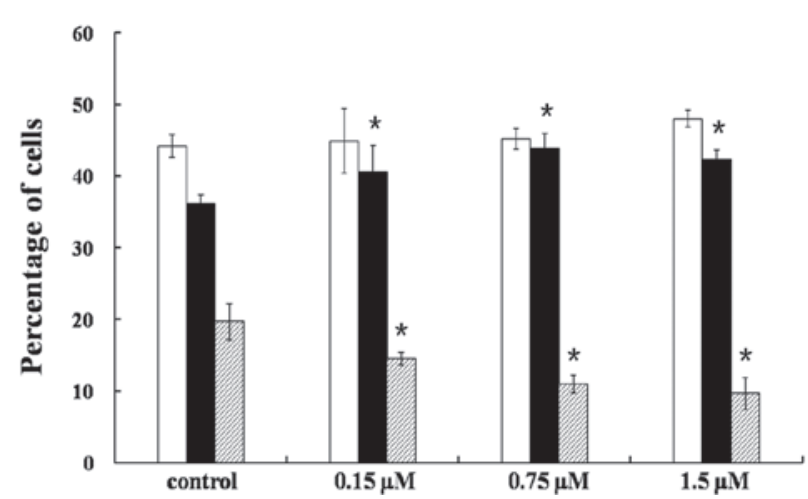

$\square \mathbf{G 1}$

$\mathbf{U S}$

口 $\mathbf{G} 2 / \mathbf{M}$

Figure 3. Effect of TCS on the cell cycle distribution of SU-DHL-2 cells. (A) The cell cycle distribution was altered, with an increase in the proportion of cells in the sub- $\mathrm{G}_{1}, \mathrm{G}_{1}$ and $\mathrm{S}$ phases, while the proportion of cells in the $\mathrm{G}_{2} / \mathrm{M}_{\text {phase }}$ was reduced. (B) The percentage of cells in the different phases of the cell cycle are presented as a histogram. TCS induced cell cycle arrest at the $\mathrm{S}$ to $\mathrm{G}_{2} / \mathrm{M}$ phase transition in SU-DHL-2 cells. " $\mathrm{P}<0.05$ vs. the control group. TCS, trichosanthin.

$\mathrm{G}_{1}, \mathrm{~S}$ and $\mathrm{G}_{2} / \mathrm{M}$ cell cycle phases was analyzed. As presented in Fig. 3A, a clear peak appeared in the TCS-treated cells prior to the $\mathrm{G}_{1}$ peak (sub- $\mathrm{G}_{1}$ population). The sub- $\mathrm{G}_{1}$ population increased in a dose-dependent manner, from $2.1-29.1 \%$ following treatment with $1.5 \mu \mathrm{M}$ TCS. In addition, cell cycle analysis indicated that treatment with TCS increased the proportion of cells in the $S$ phase, whereas cells in the $G_{2} / M$ phase were reduced from 19.7 to $9.7 \%$. The results demonstrated that the reduction in the viability of SU-DHL-2 cells induced by TCS was associated with cell cycle arrest at the $\mathrm{S}$ to $\mathrm{G}_{2} / \mathrm{M}$ phase transition $(\mathrm{P}<0.05$; Fig. $3 \mathrm{~B})$.

TCS induces apoptosis in SU-DHL-2 cells in a time- and dose-dependent manner. As the accumulation of cells in the sub- $\mathrm{G}_{1}$ phase is a potential indicator of apoptosis (20), it was further investigated whether TCS induced the apoptosis of SU-DHL-2 cells. SU-DHL-2 cells were treated with
$0.75 \mu \mathrm{M}$ TCS over different time periods (3-48 h) or $0,0.03$, 0.15 and $0.75 \mu \mathrm{M}$ TCS for $48 \mathrm{~h}$. ABT-263 was used as positive control, as it is a $\mathrm{Bcl}-2 / \mathrm{Bcl}-\mathrm{xL}$ inhibitor and apoptosis promoter (21-23). Annexin V-FITC/PI staining was used to analyze the percentage of apoptotic cells. At 3,6 and $12 \mathrm{~h}$ following TCS treatment, no significant increase in the apoptotic rates was observed. However, at 24 and $48 \mathrm{~h}$ following TCS treatment, the apoptotic rates significantly increased from $11.8 \%$ in the non-treated group to 19.9 and $44.4 \%$, respectively, in the $0.75 \mu \mathrm{M}$ TCS-treated group (Fig. 4A and B). As presented in Fig. 4C, the percentage of apoptotic cells increased from $12.2 \%$ in the non-treated group to $27.8 \%$ in the $0.15 \mu \mathrm{M}$ TCS-treated group in SU-DHL-2 cells following $48 \mathrm{~h}$ treatment. Higher doses of TCS exerted a greater effect on apoptosis, with $0.75 \mu \mathrm{M}$ TCS increasing the percentage of apoptotic cells from 12.2 to $53.5 \%$. The results demonstrated that TCS dose-dependently increased apoptosis $(\mathrm{P}<0.05$; Fig. 4D). 

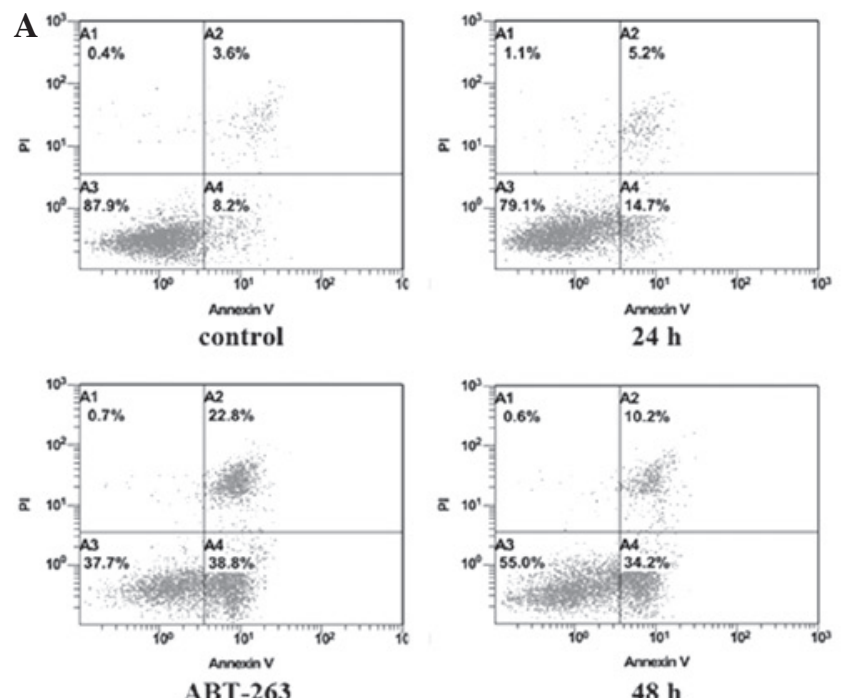

B

C
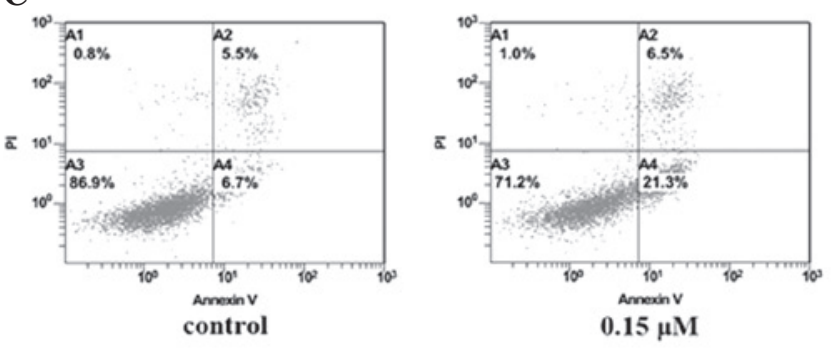

D
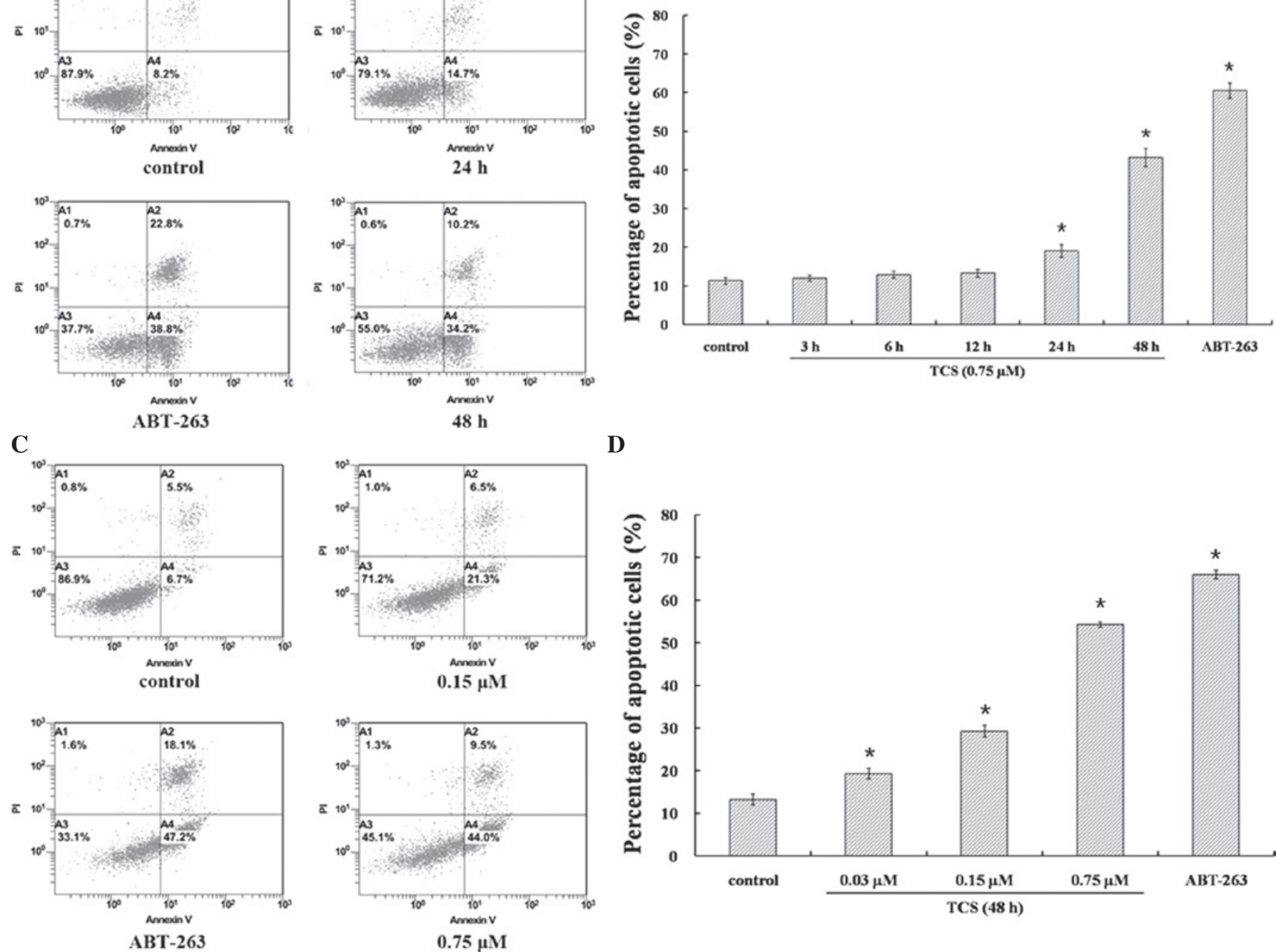

Figure 4. TCS increases the percentage of apoptotic cells in SU-DHL-2 cells. The lower right quadrant indicates the percentage of early apoptotic cells and the upper right quadrant indicates the percentage of late apoptotic cells. (A) The cells were treated with $0.75 \mu \mathrm{M} \mathrm{TCS}$ for $3,6,12,24$ and $48 \mathrm{~h}, 8 \mu \mathrm{M}$ ABT-263 was used as a positive control. (B) Histogram presenting the total percentages of apoptotic cells. (C) The cells were treated with TCS $(0.15$ or $0.75 \mu \mathrm{M})$ and ABT-263 $(8 \mu \mathrm{M})$ for $48 \mathrm{~h}$. (D) TCS increased the percentage of apoptotic cells in a dose dependent manner. ${ }^{*} \mathrm{P}<0.05$ vs. the control group (untreated cells). TCS, trichosanthin; PI, propidium iodide.

To observe the nuclear morphological alterations associated with apoptosis in TCS-treated cells, SU-DHL-2 cells were stained with Hoechst 33258. As presented in Fig. 5A and B, untreated cells exhibited normal nuclear morphology, while following treatment with $0.15 \mu \mathrm{M}$ TCS for $48 \mathrm{~h}$ or $0.75 \mu \mathrm{M}$ TCS for $24 \mathrm{~h}$, the characteristic apoptotic nuclear condensation and fragmentation were observed. This phenomenon was time- and concentration-dependent (Fig. 5C and D). Taken together, these data indicate that TCS induced apoptosis in SU-DHL-2 cells.

Induction of apoptosis through the activation of caspase-3 and -7 , and PARP-1. To investigate the apoptotic mechanisms induced by TCS, the activities of key apoptosis-associated proteins were investigated by western blot analysis. SU-DHL-2 cells were treated with different concentrations $(0.03$, 0.15 and $0.75 \mu \mathrm{M})$ of TCS for $48 \mathrm{~h}$ or $0.75 \mu \mathrm{M}$ TCS for a range of time points (3-48 h). Subsequently, the protein extracts were prepared and separated by SDS-PAGE. As presented in
Fig. 6A, significant increases in the levels cleaved caspase-3 and -7 , and PARP-1 were observed following treatment with 0.15 and $0.75 \mu \mathrm{M}$ TCS at $48 \mathrm{~h}$. As the key executioners of apoptosis, the cleavage and activation of caspase- 3 and -7 were increased with the increase in the concentration of TCS, and the downstream cleavage of PARP-1 was additionally observed in a concentration-dependent manner. As shown in Fig. 6B, the amount of cleaved caspase-3 and -7 as well as PARP-1 gradually increased following treatment with TCS for 6-48 h, while the levels of pro-caspase- 3 and -7 as well as full-length PARP-1 were reduced in parallel. Furthermore, the levels of the active fragments were markedly increased compared with the control (Fig. 6B). Therefore, the results indicate that TCS induced apoptosis in SU-DHL-2 cells through the time-dependent sequential activation of caspase-3 and -7, and PARP-1.

Involvement of various upstream caspase pathways. Apoptosis is executed by the caspase-8-mediated extrinsic pathway and/or caspase-9-dependent intrinsic pathway (24). To investigate 

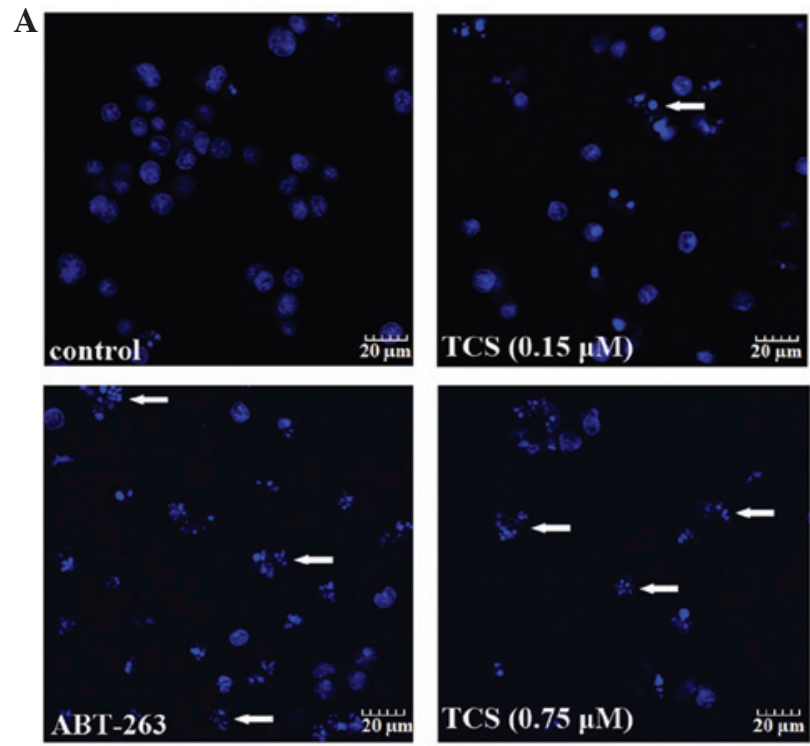

C

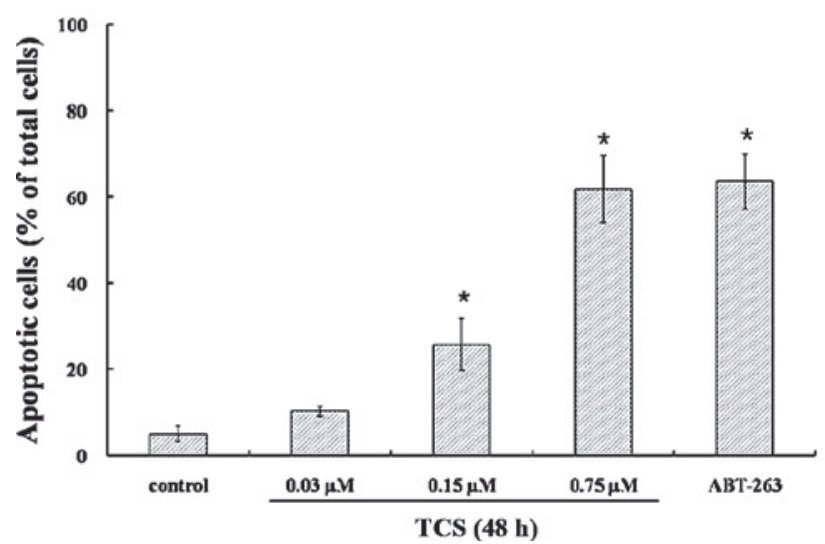

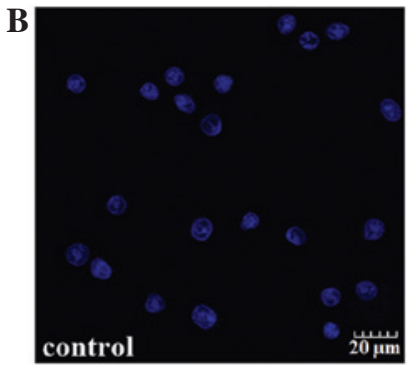
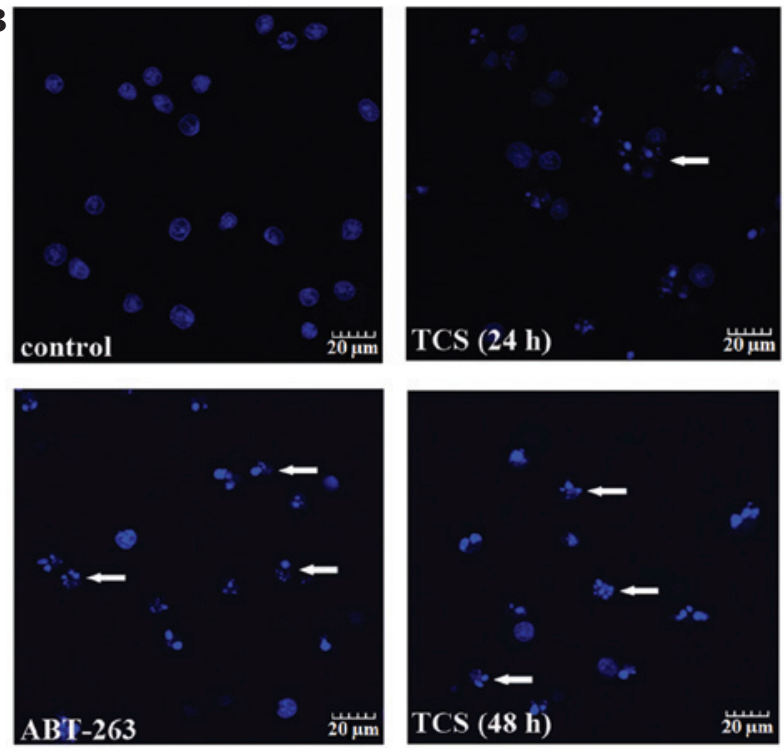

D

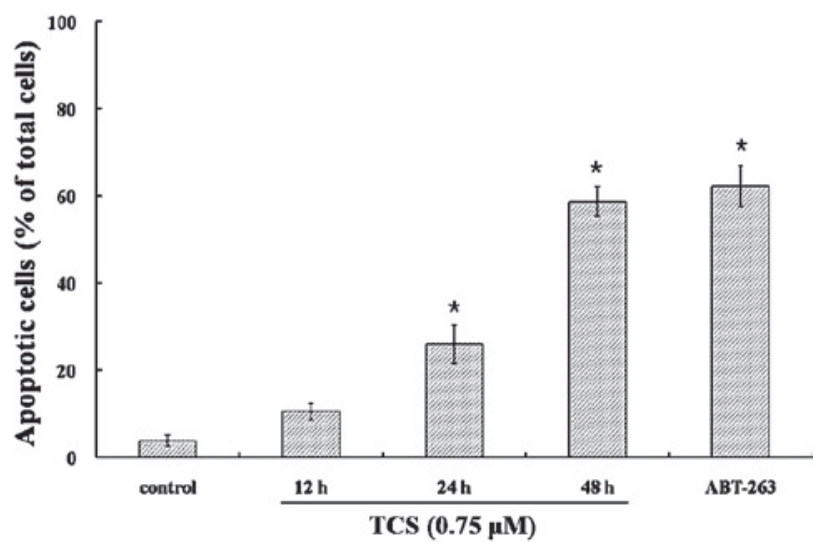

Figure 5. TCS induced the apoptosis of SU-DHL-2 cells in a time- and concentration-dependent manner. (A) Images of SU-DHL-2 cells were captured following treatment with 0.15 or $0.75 \mu \mathrm{M}$ TCS, or $8 \mu \mathrm{M}$ ABT-263 for $48 \mathrm{~h}$. (B) Cells were treated with $0.75 \mu \mathrm{M}$ TCS for 24 or $48 \mathrm{~h}$ or $8 \mu \mathrm{M}$ ABT-263. Histograms show the percentage change in the number apoptotic cells (C) following treatment with different doses of TCS and (D) following different exposure times. Arrows indicate apoptotic cells with characteristic nuclear condensation and fragmentation. Scale bars, $20 \mu \mathrm{m}$. ${ }^{*} \mathrm{P}<0.05 \mathrm{vs}$. the control.

whether these pathways were activated in TCS-induced cell apoptosis, caspase activity was inhibited using Z-VAD-FMK (pan-caspase inhibitor), Z-IETD-FMK (caspase-8 inhibitor) and Z-LEHD-FMK (caspase-9 inhibitor), and the percentage of apoptotic cells was measured using flow cytometry. SU-DHL-2 cells were treated with $0.75 \mu \mathrm{M}$ TCS combined with $20 \mu \mathrm{M}$ Z-VAD-FMK for $48 \mathrm{~h}$, and the Z-VAD-FMK treatment was observed to markedly inhibit TCS-induced apoptosis from 46.0 to $16.1 \%$, indicating that TCS-induced cell death involved caspase activation $(\mathrm{P}<0.05$; Fig. $7 \mathrm{~A}$ and $\mathrm{B})$. Notably, treatment with Z-IETD-FMK $(20 \mu \mathrm{M})$ or Z-LEHD-FMK $(20 \mu \mathrm{M})$ significantly reduced the percentage of TCS-induced apoptotic cells from 40.6 to 27.4 or $34.7 \%$, respectively (Fig. 7C and D). These results suggest that the extrinsic and intrinsic apoptotic pathways were involved in TCS-induced apoptosis.

\section{Discussion}

TCS has been used as an anti-inflammatory agent in traditional Chinese medicine for over a century in China $(1,25)$. More recently, TCS has been investigated due to its potential antitumor activity. An advantage of TCS compared with standard chemotherapy is that TCS has selective toxicity for tumor cells, with minimal effect on normal cells (4). TCS has been demonstrated to induce the apoptosis of choriocarcinoma (6), leukemia and lymphoma $(4,10)$, gastric carcinoma (26), cervical cancer (5) and hepatoma (27) cells. In the present study, TCS was demonstrated to exhibit potent antitumor activity toward thirteen lymphoma cell lines. The cell line with the greatest sensitivity to TCS was SU-DHL-2. TCS was able to reduce SU-DHL-2 cell viability at low concentrations. Therefore, SU-DHL-2 cells were selected for further investigation. In addition, these data demonstrated that the effects of TCS were dependent on the dose and exposure duration.

DLBCL, the most common subtype of non-Hodgkin's lymphoma, has a relatively favorable prognosis. However, despite attempts to increase the efficacy of conventional chemotherapy during the past decade, it remains that $\sim 40 \%$ of DLBCL patients fail to respond to treatment with R-CHOP (rituximab, cyclophosphamide, doxorubicin, vincristine and prednisone)-like regimens (28). Of those patients that are treatment-resistant or have relapsed, only 30-35\% achieve 
A
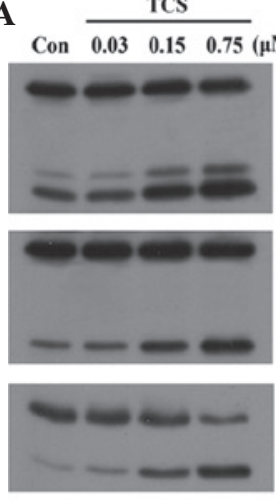

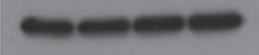

(AB) Con $\mathrm{ABT}-263$

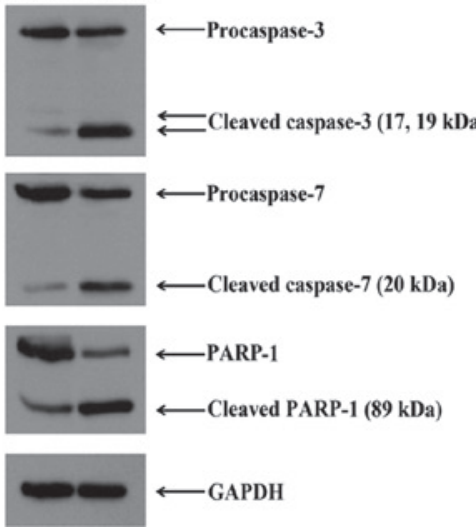

B
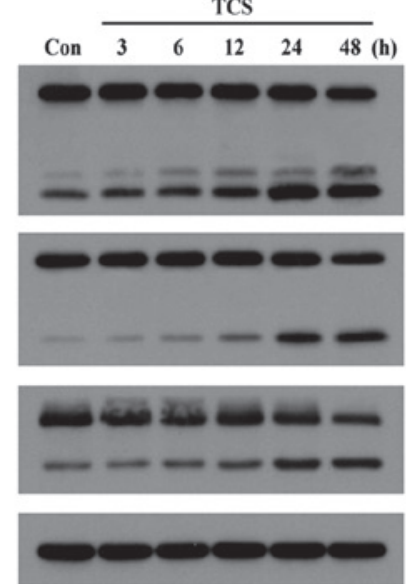

Con ABT-263
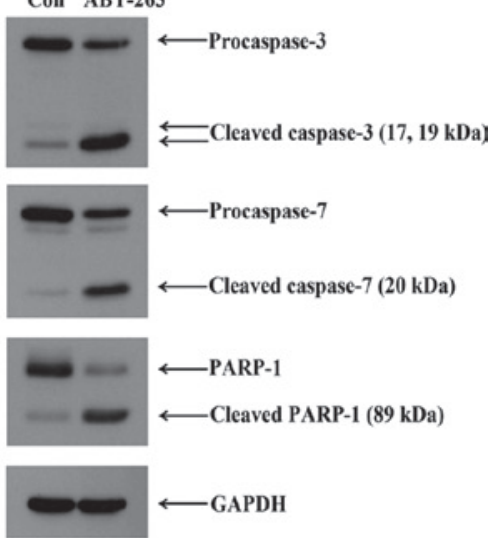

Figure 6. Effect of TCS on the expression of apoptosis-associated proteins. (A) To examine the dose-dependent effects, SU-DH-2 cells were treated with TCS $(0.03,0.15$ and $0.75 \mu \mathrm{M})$ and $8 \mu \mathrm{M}$ ABT- 263 for $48 \mathrm{~h}$. Activated caspase-3 and -7 , and cleaved PARP-1 were observed in a dose-dependent manner. (B) To examine the time-dependent effects, SU-DH-2 cells were treated with TCS $(0.75 \mu \mathrm{M})$ for 3, 6, 12, 24 or $48 \mathrm{~h}$. The activation of caspase-3 and -7, and PARP-1 was maximal at $48 \mathrm{~h}$, and TCS induced apoptosis in a time-dependent manner. The experiments were repeated three times with similar results. TCS, trichosanthin; Con, control; PARP-1, poly (ADP-ribose) polymerase 1; GAPDH, glyceraldehyde 3-phosphate dehydrogenase.

prolonged progression-free survival with high-dose chemotherapy followed by autologous stem cell transplantation (29). The present study demonstrated clear reductions in the viability of SU-DHL-2 cells treated with TCS, indicating it may be a novel strategy and aid in the improvement of outcomes for patients with DLBCL who are treatment-resistant or have relapsed.

To date, the precise mechanisms of TCS-mediated inhibition of tumor growth remain poorly characterized. Potential mechanisms involved include the cyclic adenosine monophosphate signaling pathways (30), caspase family members and the mitochondrial apoptotic pathway (31), in addition to the regulation of apoptosis-associated genes and (32) the cytoskeleton (3). To elucidate the mechanisms of action of TCS, the current study investigated apoptotic induction and cell cycle arrest at the cellular and molecular levels. Cell cycle distribution was observed using PI single staining. The percentage of cells at the sub- $\mathrm{G}_{1}$ phase was increased significantly in the TCS-treated groups compared with the control group. In addition, flow cytometric analysis using Annexin V-FITC/PI indicated that TCS induced early apoptosis in SU-DHL-2 cells in a dose-dependent manner. It was observed that the cells undergo apoptotic cell death at 24 and $48 \mathrm{~h}$ following TCS treatment $(0.75 \mu \mathrm{M}$; Fig. 4$)$. When the cells were incubated with TCS for $48 \mathrm{~h}, 21.3 \%$ of cells were observed to undergo early stage apoptosis in the $0.15 \mu \mathrm{M}$ TCS group, which is significantly greater than the control group (6.7\%). Furthermore, the appearance of apoptotic nuclei was observed in cells treated with TCS.

In further investigations of apoptosis induced by TCS, it was observed that TCS-induced apoptosis was associated with caspase activation. The cleavage of caspase- 3 and -7, and PARP-1 was observed in the TCS-treated groups in a dose- and time-dependent manner. Caspases are cysteine proteases that have critical roles in the coordination of apoptosis, and cleave target proteins to execute cell death $(13,17,33)$. Caspase is a key contributor to the cell disassembly observed in apoptosis, via the targeting of structural substrates including nuclear laminins, focal adhesion sites and cell-cell adherence junctions (34-37). In addition to caspase-3, caspase-7 is activated during the execution phase of apoptosis, and its functions partially overlap with caspase-3, such that caspase-3-deficient cells continue to execute apoptosis in the presence of caspase-7 (38). A previous study demonstrated that the deficiency of both caspase-3 and caspase-7 is required to entirely prevent the activation of apoptosis (39). In the current study, cleavage of both caspase- 3 and caspase- 7 was observed in TCS-treated SU-DHL-2 cells.

To investigate the role of the caspase cascade in TCS-induced cell death, Z-VAD-FMK, a pan-caspase inhibitor, was used. The ability of TCS to induce apoptosis was inhibited by Z-VAD-FMK in SU-DHL-2 cells, demonstrating that TCS-induced apoptosis is caspase-dependent. Caspases are the principal effectors of apoptosis and are involved in pathways such as the caspase-8-regulated extrinsic and caspase-9-regulated intrinsic pathways. The caspase-9 pathway links mitochondrial damage to caspase activation, and serves as an index of decreased mitochondrial membrane function. In a previous study, TCS has been reported to induce apoptosis by the activation of the caspase-8- and caspase-9-regulated pathways in breast cancer cells (7). To investigate the involvement of caspase- 8 and -9 in TCS-induced apoptosis, SU-DHL-2 cells were treated with Z-IETD-FMK or Z-LEHD-FMK and co-treated with TCS. The results demonstrated that Z-IETD-FMK reduced the percentage of apoptotic cells induced by TCS. However, Z-LEHD-FMK was observed to reduce the level of apoptotic cells to a lesser extent than Z-IETD-FMK. Thus, TCS-induced apoptosis of SU-DHL-2 cells is dependent on caspase- 9 and caspase- 8 , which indicates that TCS induces apoptosis via the mitochondrial-dependent and the death receptor pathways, with the caspase-8-mediated extrinsic death receptor pathway having greater involvement. Further investigation of these pathways is required to fully elucidate the apoptotic mechanisms involved. Taken together, these data indicate that the cell-death inducing activity of TCS is associated with apoptosis.

Alterations in the regulation of the cell cycle serves a key role in the growth of numerous types of cancer and is an 

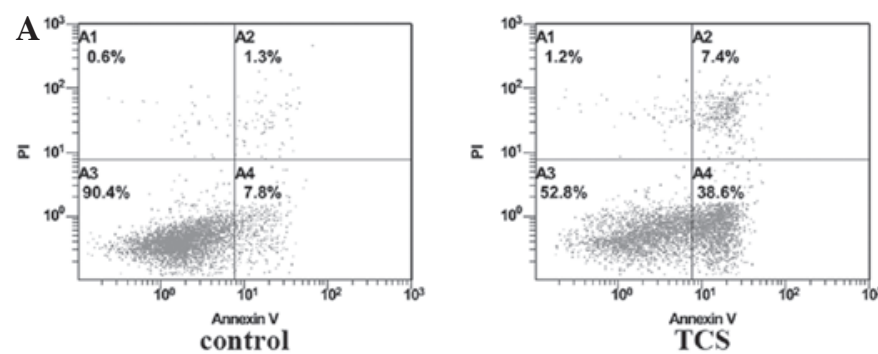

B
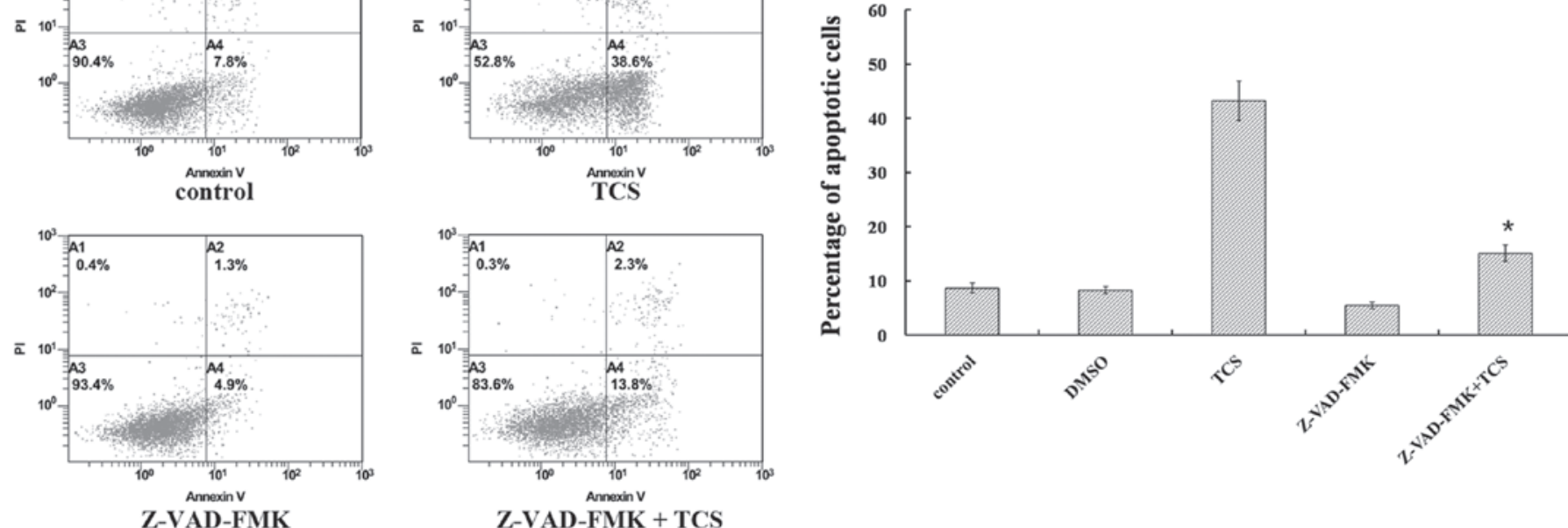

C
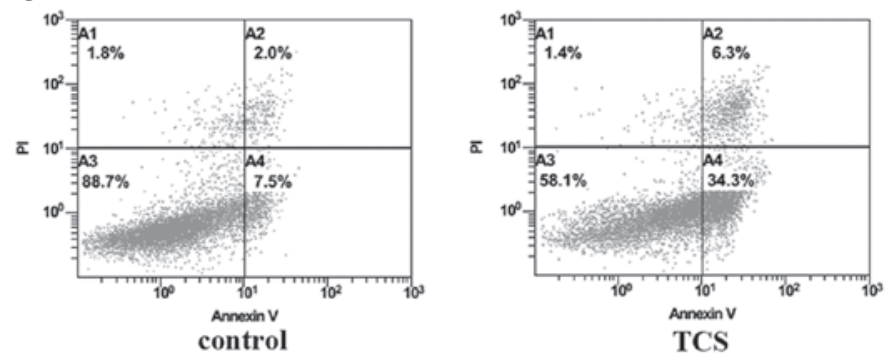

D

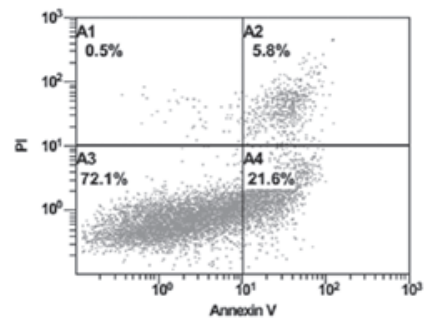

Z-IETD-FMK + TCS
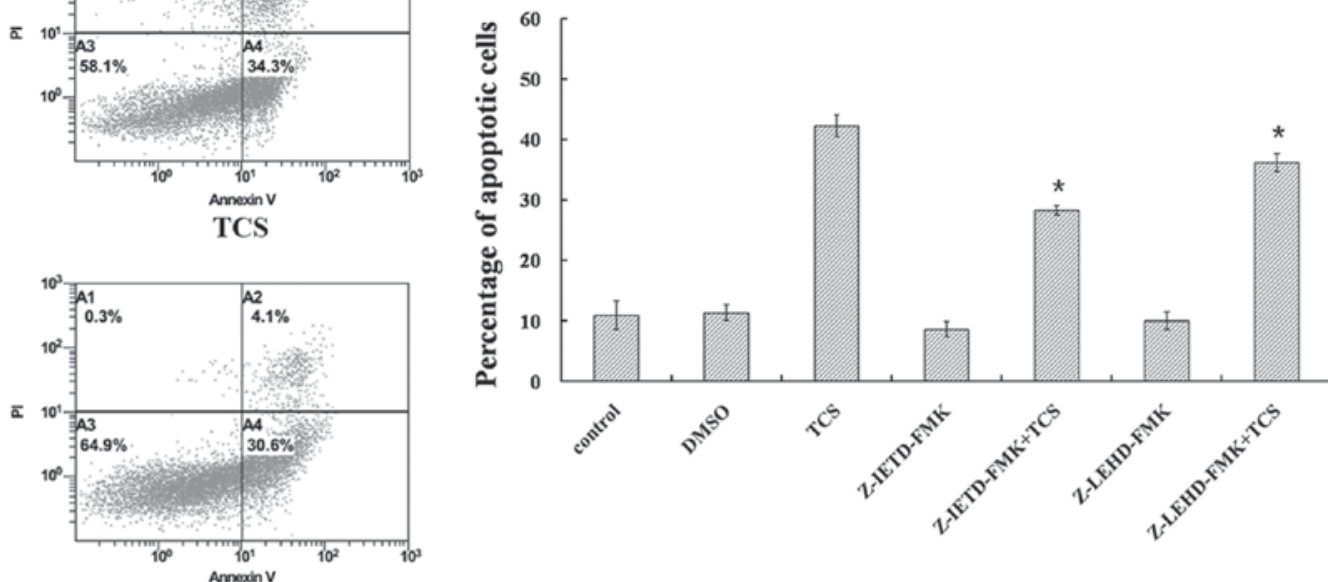

Figure 7. Caspase inhibitors reduced apoptosis in SU-DHL-2 cells. SU-DHL-2 cells were treated with $0.75 \mu \mathrm{M}$ TCS and were incubated with the caspase inhibitors for $48 \mathrm{~h}$. (A) Z-VAD-FMK (pan-caspase inhibitor, $20 \mu \mathrm{M}$ ) treatment inhibited TCS-induced apoptosis. (B) Histogram shows the percentage of apoptotic cells. (C) Treatment with Z-IETD-FMK (caspase-8 inhibitor, $20 \mu \mathrm{M}$ ) or Z-LEHD-FMK (caspase-9 inhibitor, $20 \mu \mathrm{M}$ ) reduced TCS-induced apoptosis. (D) Histogram shows the percentage of apoptotic cells. Values are presented as the mean \pm standard deviation. ${ }^{*} \mathrm{P}<0.05$ vs. the TCS-treated group. TCS, trichosanthin; Z-VAD-FMK, Carbobenzoxy-val-ala-asp-(OMe)-fluoromethylketone; Z-IETD-FMK, Z-ile-glu(OMe)-thr-asp(OMe)-FMK; Z-LEHD-FMK, Z-leu-glu(OMe)-his-asp(OMe)-FMK; PI, prodidium iodide; DMSO, dimethyl sulfoxide.

important target in cancer therapy (40). $\mathrm{G}_{1}$ phase arrest by TCS has been previously reported in breast cancer cells (7) and A549 lung cancer cells (41). In the current study, TCS induced an increase in the percentage of cells in the $\mathrm{S}$ phase in SU-DHL-2 cells. For a cell to be able to divide into two daughter cells, the synthesis and duplication of the DNA are a requirement, and any abnormality in this would lead to an obstacle in cell cycle progression. Numerous checkpoints exist to aid cells in the identification and repair of DNA damage by halting/stalling the progression through the phases of the cell cycle, including the $\mathrm{G}_{0} / \mathrm{G}_{1}, \mathrm{~S}$ and $\mathrm{G}_{2} / \mathrm{M}$ checkpoints (40). The current study observed arrest at the $S$ to $\mathrm{G}_{2} / \mathrm{M}$ phase transition of the cell cycle upon TCS treatment, leading to a halt in cell cycle progression.

In conclusion, these data indicate that TCS reduced cell viability in a dose- and time-dependent manner in SU-DHL-2 lymphoma cells. This effect of TCS may be attributed to the induction of apoptosis and the arrest in the $\mathrm{S}$ phase of the cell cycle in SU-DHL-2 cells. To the best of our knowledge, the current study demonstrated for the first time that the TCS-induced apoptosis of SU-DHL-2 cells was associated with the activation of the extrinsic and intrinsic pathways. However, the precise mechanisms and the molecular mediators that result in the initiation of apoptosis remain to be elucidated. Thus, further studies on TCS as a novel chemotherapeutic agent are required.

\section{Acknowledgements}

The current study was supported by Fundamental Research Funds for the Development of Strategic Emerging Industries in Shenzhen, China (grant no. JCYJ20120613113228732) and 
Science and Technology Research Project of Shenzhen, China (grant no. JSGG20150512162446307).

\section{References}

1. Shaw PC, Lee KM and Wong KB: Recent advances in trichosanthin, a ribosome-inactivating protein with multiple pharmacological properties. Toxicon 45: 683-689, 2005.

2. Zhang XJ and Wang JH: Homology of trichosanthin and ricin A chain. Nature 321: 477-478, 1986.

3. Li M, Li X and Li JC: Possible mechanisms of trichosanthin-induced apoptosis of tumor cells. Anat Rec (Hoboken) 293: 986-992, 2010.

4. Zheng YT, Zhang WF, Ben KL and Wang JH: In vitro immunotoxicity and cytotoxicity of trichosanthin against human normal immunocytes and leukemia-lymphoma cells. Immunopharmacol Immunotoxicol 17: 69-79, 1995.

5. Ru QH, Luo GA, Liao JJ and Liu Y: Capillary electrophoretic determination of apoptosis of HeLa cells induced by trichosanthin. J Chromatogr A 894: 165-170, 2000.

6. Zhang C, Gong Y, Ma H, An C, Chen D and Chen ZL: Reactive oxygen species involved in trichosanthin-induced apoptosis of human choriocarcinoma cells. Biochem J 355: 653-661, 2001

7. Fang EF, Zhang CZ, Zhang L, Wong JH, Chan YS, Pan WL, Dan XL, Yin CM, Cho CH and Ng TB: Trichosanthin inhibits breast cancer cell proliferation in both cell lines and nude mice by promotion of apoptosis. PLoS One 7: e41592, 2012.

8. Liu F, Wang B, Wang Z and Yu S: Trichosanthin down-regulates Notch signaling and inhibits proliferation of the nasopharyngeal carcinoma cell line CNE2 in vitro. Fitoterapia 83: 838-842, 2012.

9. Zhang K, Xu J, Huang X, Wu L, Wen C, Hu Y, Su Y, Chen Y and Zhang Z: Trichosanthin down-regulated p210Bcr-Abl and enhanced imatinib-induced growth arrest in chronic myelogenous leukemia cell line K562. Cancer Chemother Pharmacol 60: 581-587, 2007.

10. Wang YY, Ouyang DY and ZhengxYT: Mechanism of trichosanthin against human leukemia/lymphoma cells in vitro. Zhongguo Shi Yan Xue Ye Xue Za Zhi 15: 729-732, 2007 (In Chinese).

11. Herr I and Debatin KM: Cellular stress response and apoptosis in cancer therapy. Blood 98: 2603-2614, 2001.

12. Hu W and Kavanagh JJ: Anticancer therapy targeting the apoptotic pathway. Lancet Oncol 4: 721-729, 2003.

13. Zimmermann KC, Bonzon C and Green DR: The machinery of programmed cell death. Pharmacol Ther 92: 57-70, 2001.

14. Dias N and Bailly C: Drugs targeting mitochondrial functions to control tumor cell growth. Biochem Pharmacol 70: 1-12, 2005.

15. Schulze-Osthoff K, Ferrari D, Los M, Wesselborg S and Peter ME: Apoptosis signaling by death receptors. Eur J Biochem 254: 439-459, 1998.

16. Luo X, Budihardjo I, Zou H, Slaughter C and Wang X: Bid, a $\mathrm{Bcl} 2$ interacting protein, mediates cytochrome $\mathrm{c}$ release from mitochondria in response to activation of cell surface death receptors. Cell 94: 481-490, 1998.

17. Budihardjo I, Oliver H, Lutter M,Luo X and Wang X: Biochemical pathways of caspase activation during apoptosis. Annu Rev Cell Dev Biol 15: 269-290, 1999.

18. ShiZ, Liang YJ, Chen ZS, Wang XW, Wang XH, Ding Y, Chen LM, Yang XP and Fu LW: Reversal of MDR1/P-glycoprotein-mediated multidrug resistance by vector-based RNA interference in vitro and in vivo. Cancer Biol Ther 5:39-47, 2006.

19. Fang EF, Ng TB, Shaw PC and Wong RN: Recent progress in medicinal investigations on trichosanthin and other ribosome inactivating proteins from the plant genus Trichosanthes. Curr Med Chem 18: 4410-4417, 2011.

20. Galluzzi L, Aaronson SA, Abrams J, Alnemri ES, Andrews DW, Baehrecke EH, Bazan NG, Blagosklonny MV, Blomgren K, Borner C, et al: Guidelines for the use and interpretation of assays for monitoring cell death in higher eukaryotes. Cell Death Differ 16: 1093-1107, 2009.
21. Anderson MA, Huang D and Roberts A: Targeting BCL2 for the treatment of lymphoid malignancies. Semin Hematol 51: 219-227, 2014

22. Shi J, Zhou Y, Huang HC and Mitchison TJ: Navitoclax (ABT-263) accelerates apoptosis during drug-induced mitotic arrest by antagonizing Bcl-xL. Cancer Res 71: 4518-4526, 2011.

23. Levesley J, Steele L, Taylor C, Sinha P and Lawler SE: ABT-263 enhances sensitivity to metformin and 2-deoxyglucose in pediatric glioma by promoting apoptotic cell death. PLoS One 8: e64051, 2013

24. Bao Q and Shi Y: Apoptosome: A platform for the activation of initiator caspases. Cell Death Differ 14: 56-65, 2007.

25. Zhao J, Ben LH, Wu YL, Hu W, Ling K, Xin SM, Nie HL, Ma L and Pei G: Anti-HIV agent trichosanthin enhances the capabilities of chemokines to stimulate chemotaxis and $\mathrm{G}$ protein activation, and this is mediated through interaction of trichosanthin and chemokine receptors. J Exp Med 190: 101-111, 1999.

26. Xu J, Gao DF, Yan GL and Fan JM: Induced apoptotic action of recombinant trichosanthin in human stomach adenocarcinoma MCG803 cells. Mol Biol Rep 36: 1559-1564, 2009.

27. Li M, Chen F, Liu CP, Li DM, Li X, Wang C and Li JC: Dexamethasone enhances trichosanthin-induced apoptosis in the HepG2 hepatoma cell line. Life Sci 86: 10-16, 2010.

28. Vacirca JL, Acs PI, Tabbara IA, et al: Bendamustine combined with rituximab for patients with relapsed or refractory diffuse large B cell lymphoma. Ann Hematol 93: 403-409, 2014.

29. Friedberg JW and Fisher RI: Diffuse large B-cell lymphoma. Hematol Oncol Clin North Am 22: 941-952, 2008.

30. Wang P, Yan H and Li JC: CREB-mediated Bcl-2 expression in trichosanthin-induced Hela cell apoptosis. Biochem Biophys Res Commun 363: 101-105, 2007.

31. Li J, Xia X, Ke Y, Nie H, Smith MA and Zhu X: Trichosanthin induced apoptosis in HL-60 cells via mitochondrial and endoplasmic reticulum stress signaling pathways. Biochim Biophys Acta 1770: 1169-1180, 2007.

32. Huang H, Chan H, Wang YY, Ouyang DY, Zheng YT and Tam SC: Trichosanthin suppresses the elevation of p38 MAPK, and Bcl-2 induced by HSV-1 infection in Vero cells. Life Sci 79: 1287-1292, 2006

33. Boland K, Flanagan L and Prehn JH: Paracrine control of tissue regeneration and cell proliferation by Caspase-3. Cell Death Dis 4: e725, 2013.

34. Brancolini C, Lazarevic D, Rodriguez J and Schneider C: Dismantling cell-cell contacts during apoptosis is coupled to a caspase-dependent proteolytic cleavage of beta-catenin. J Cell Biol 139: 759-771, 1997.

35. Kook S, Kim DH, Shim SR, Kim W, Chun JS and Song WK: Caspase-dependent cleavage of tensin induces disruption of actin cytoskeleton during apoptosis. Biochem Biophys Res Commun 303: 37-45, 2003

36. Taylor RC, Cullen SP and Martin SJ: Apoptosis: Controlled demolition at the cellular level. Nat Rev Mol Cell Biol 9: 231-241, 2008.

37. Kothakota S, Azuma T, Reinhard C, Klippel A, Tang J, Chu K, McGarry TJ, Kirschner MW, Koths K, Kwiatkowski DJ and Williams LT: Caspase-3-generated fragment of gelsolin: Effector of morphological change in apoptosis. Science 278: 294-298, 1997.

38. Zheng TS, Hunot S, Kuida K, Momoi T, Srinivasan A, Nicholson DW, Lazebnik Y and Flavell RA: Deficiency in caspase- 9 or caspase-3 induces compensatory caspase activation. Nat Med 6: 1241-1247, 2000.

39. Lakhani SA, Masud A, Kuida K, Porter GA Jr, Booth CJ, Mehal WZ, Inayat I and Flavell RA: Caspases 3 and 7: Key mediators of mitochondrial events of apoptosis. Science 311: 847-851, 2006

40. Arora S and Tandon S: Achyranthes aspera root extracts induce human colon cancer cell (COLO-205) death by triggering the mitochondrial apoptosis pathway and $\mathrm{S}$ phase cell cycle arrest. ScientificWorldJournal 2014: 129697, 2014.

41. Li CT, Lin CH, Kao TY, Wu MF, Yeh CS, Yeh KT and Ko JL: The mechanisms of action of Tianhua $\left({ }^{\mathrm{TM}}\right)$ on antitumor activity in lung cancer cells. Pharm Biol 48: 1302-1309, 2010. 